\title{
MARRIAGEABLE AGE: POLITICAL DEBATES ON EARLY MARRIAGE IN TWENTIETH- CENTURY INDONESIA
}

\section{Susan Blackburn and Sharon Bessell}

The purpose of this article is to show how the age of marriage, especially for girls, became a political issue in twentieth century Indonesia, and to investigate the changing intensity, focus, and participation in the debate over the issue. Compared with India, the incidence of very early marriage among Indonesian girls appears never to have been exceptionally high, yet among those trying to "modernize" Indonesia the fact that parents married off their daughters at or before the onset of puberty was considered a "social evil." Social reformers differed as to the reasons for their concern and as to what action should be taken and by whom. In particular there were strong disagreements about whether government intervention was either desirable or effective in raising the age of marriage.

The age at which it is appropriate for girls to marry has been a contentious matter in many countries in recent centuries. In societies where marriage was considered to be the prerogative of families, the children themselves were rarely consulted and the age of marriage, or at least of betrothal, was likely to be quite young, before children could exert their own will. Although physical readiness for sexual intercourse and childbearing was a consideration, this was a matter to be supervised by adult kin, and the wedding could, if necessary, be timed so that it occurred separately from the consummation of marriage. Apart from families, the only other institutions directly concerned with marriage were likely to be religious ones.

It has been considered a mark of modernity that decision-making about marriage becomes less collective and more individualistic, passing from parents or older kin to 
108 Susan Blackburn and Sharon Bessell

the two people most directly concerned. In this process, age of marriage becomes relevant: only those who are sufficiently mature and well-informed are considered capable of making decisions about their adult life and bearing its responsibilities. This change is associated with wider notions of a demarcation between childhood and adulthood, and the sanctity of childhood is not entrusted solely to families and religious bodies but is now also the concern of the state, as illustrated by laws relating to, for instance, the age of consent to sexual intercourse, of employment, and of legal liability as well as of marriage. In "modern" societies, precise age is an important legal matter and is established by careful official documentation. In many countries the change in social attitudes and the intrusion of the state into such age-related issues has been associated with considerable public controversy, and Indonesia is no exception.

Indonesia in the twentieth century has seen the gradual and often disputed emergence of "modern" ideas about marriageable age. Before this century, few Indonesians knew their precise chronological age because birth records were rarely kept, and marriages tended to occur early under the supervision of kin and religious (primarily Islamic) authorities. Dutch colonial rule caused the question of marriage age to become a political issue, as Western education introduced by the Dutch spread notions of individual rights and the state extended its control over family life. After independence in 1945 the nature of the debate about early marriage changed: the Indonesian state had greater legitimacy in the realm of social reform, the arguments in favor of later marriage shifted somewhat, and new players entered the scene. For this reason, this article is divided into two main chronological sections, dealing with the periods before and after independence.

\section{Part I. The debate about "child marriage" in the Dutch East Indies}

During the colonial period, public debate about early marriage was framed in the context of "child marriage." In the lexicon of social reformers, child marriage is a term of opprobrium. Almost exclusively associated with girls, it carries overtones of child sexual abuse, of precipitating children too early into adulthood, and at the very least of depriving them of the right to choose their spouse. Differing attitudes to child marriage formed part of the clash of cultures between "modern" and "backward" peoples which characterized many colonial situations, not only in the Dutch East Indies.

The best documented case illustrating the political debates and struggles prompted by child marriage traditions is undoubtedly British India, where the problem of Hindu child brides was compounded by a stigma against divorce and widowhood and the tragedy of sati. Campaigns by Indian and British reformers led to legislation being passed by the colonial government against child marriage, notably the Child Marriage Restraint Act of 1929.1

Compared to British India, the politics of child marriage in the Dutch East Indies was more muted and did not result in legislation. Ending child marriage was, however, a cause close to the hearts of social reformers in different camps: Dutch and Indonesian women, Javanese priyayi (civil servants), Indonesian secular nationalists,

${ }^{1}$ See Geraldine H. Forbes, "Women and Modernity: the issue of child marriage in India," Women's Studies International Quarterly 2 (1979): 407-419. 
and Dutch colonial authorities. Although the actual incidence of child marriage in the Indies was unclear, such people judged it to be unacceptably high. Being Muslims, most Indonesians contracted marriages under Islamic law, which stipulated no minimum age. Girls need not personally agree to marriage; consent could be given on their behalf by their male wali-mujbir (literally "coercive guardian"), a father or grandfather. Those who opposed child marriage did so on a number of grounds associated with "modern" values: protection of children (especially from sexual abuse), championing of the rights of girls to determine their own futures, and the need for a modern, respected nation to be based on strong, stable families. All these reformers can be seen as participating in a common project of refashioning the Indonesian family in line with "modern" notions of childhood and motherhood. The "modern" family was to be built on new foundations, purged of pernicious customs like polygamy and child marriage, and incorporating new virtues derived from schooling and science. In many respects, these notions could also be seen as importing bourgeois Western values into the colony. ${ }^{2}$

A formidable array of factors confronted campaigners for change. Those Muslims who supported the rights of Islam and those parents and kin who wished to maintain control of children both had vested interests in traditional arranged marriages. What's more, the practical obstacles to initiating reform were daunting. The only accurate age data available for Indonesians related to a few Christian groups in the Outer Islands. ${ }^{3}$.In many cases, too, the formal wedding ceremony was not immediately followed by cohabitation or physical consummation, which might be postponed for months or years, thus confusing the issue of alleged physical damage to pre-pubescent wives.

\section{Early statements by Indonesian women}

From early in the twentieth century, Indonesian women who had received a Western education began to draw attention to the problem of child marriage. It was not always described in quite those terms; more often the objection was to the practice described as "forced marriage": the custom of parents marrying off their daughters without consulting them. The younger the child, of course, the easier this was for parents to do. One of the earliest cries of outrage came from R. A. Kartini, a consistent opponent of customs which she considered oppressive to women. Thus in 1901 she wrote to her Dutch friend Mevrouw Abendanon about the marriage of Mini, the daughter of the Regent of Ciamis:

Her mother is apparently an extremely refined and cultured woman-and she is marrying off her thirteen-year-old child! .. . I had tears of rage and regret and desperation in my eyes-and especially of sympathy for that poor child when I read the announcement of the proposed marriage. Mini, that dear, wonderful child, who had such a promising future-marrying - that young thing! - oh, I still cannot imagine it. It is outrageous! Oh, do not create illusions which must be

2 For more analysis of colonialism as a bourgeois project, see Ann Laura Stoler, Race and the Education of Desire: Foucault's History of Sexuality and the Colonial Order of Things (Durham: Duke University Press, 1995).

3 These groups were the Ambonese, Minahasans, Sangirese and Talaudans. See Volkstelling 1930, vol. 8 (Batavia, Landsdrukkerij, 1936), p. 49. 
110 Susan Blackburn and Sharon Bessell

destroyed-do not encourage dreams, when one knows beforehand that rude awakening must follow. It is cruel-cruel! 4

The letter shows at once how much Kartini had absorbed from her Dutch friends and teachers: to her Mini at thirteen was still a child, and she felt that the girl's dreams of a "promising future" had been betrayed. As a young woman of the same priyayi class, Kartini found it easy to imagine that Mini entertained dreams similar to her own, the result of exposure to a world beyond the narrow one inhabited by priyayi girls where early marriage like this was not unusual and was seen by many merely to mark a transition into adulthood.

Although there are no good statistics, anecdotal evidence makes it appear likely that in the early twentieth century early marriage was quite common in much of the archipelago and among most classes. Certainly the first heads of Kartini schools, private elementary schools established for girls by the Dutch in Java from 1913 onwards, frequently reported that pupils of twelve to fourteen years were withdrawn from studies by their parents because they were to be married. ${ }^{5}$

Not only young women like Kartini, members of Javanese priyayi families, were beginning to protest against being married off by their parents. In the 1910s young West Sumatran women wrote to the weekly newspaper for women, Soenting Melajoe (Malay Ornament), taking a stand against parental pressure to marry early. Thus in 1912, Zahara from Fort de Kock (Bukittinggi) wrote under the heading "Undesirable customs of ours":

One of these customs is parents marrying young girls to old men. A girl of fourteen is still childlike in her thinking, certainly not yet ready for an old man. It will lead to divorce-the child will become single by age fifteen. Then she marries again with a man of rank, but because she is forced into the marriage by her mother, not long afterwards she divorces again. Thus, with a girl who is forced to marry against her will, by the time she is twenty she will have divorced three or four times.

How bad this is!!! Abandon this bad custom, copy the Europeans! 6

In the following week she continued her tirade, urging parents not to marry "your child until she has finished her schooling and has mastered housework" and "until she has reached intellectual maturity [sempurna betul akalnya]." 7 The view strongly expressed here is that a girl must be allowed to attain the adult qualities required of a wife and mother, so that her marriage can be stable; otherwise divorce, with all its undesirable consequences, will result. A couple of years later in the same paper, Djoeriah of Payakumbuh voiced similar concerns about parents "arranging marriage without consulting the daughter," even marrying young women to old men for the sake of acquiring sons-in-law of high rank. "It makes the girl unhappy, but her parents

\footnotetext{
4 Joost Cote (transl.), Letters from Kartini (Clayton, Monash Asia Institute, 1992), p. 121.

${ }^{5}$ See the open letter on this topic from the head of the Semarang Kartini school, Mej. F. S. Schippers, to the wife of the Governor-General, printed in Javabode and reproduced in De Indische Gids 1917 Part II, pp. 12101214. Also Vereeniging Kartinifonds, Jubileum-Verslag uitgegeven ter gelegenheid van het 25-jarig bestaan der Vereeiniging Kartinifonds door den Raad van Beheer, 1913-1938 (n.pl., n.d.), pp. 46 and 64.

6 Soenting Melajoe 1, 19 (November 9, 1912).

7 Soenting Melajoe 1, 20 (November 16, 1912).
} 
don't care." 8 Here the parents are clearly characterized as selfish people indifferent to the personal welfare of the child.

In West Sumatra, the conservative group (kaum kuno) resisted arguments voiced by those of the kaum muda (literally: "young group") keen to adopt "modern" ways that favored a larger degree of individual freedom. ${ }^{9}$ One daring contribution in Soenting Melajoe advocated that girls should not be married before age eighteen (because otherwise "her body will quickly deteriorate" and "if she gives birth to a child, she won't know how to look after it") and that it should be left to the girl herself to find the husband ("Girls are human, aren't they? They also have brains"). ${ }^{10}$ This brought a heated response from a male member of the old guard, who argued that age eighteen might be suitable for a cold country but not for the Indies, on the grounds that in hot climates children matured faster. Moreover, he argued, it was ridiculous to say that until age eighteen girls did not know how to look after children, since most had looked after younger siblings. If the girl had menstruated and reached age fifteen, she was old enough to marry.

It is right for parents to choose the husband. And among us [matrilineal] Minangkabaus, the rights of ninik mamak [male elders] must be consulted.

If you leave it to a girl, she may be tricked into marriage by a womanizer or misled by men who deceive girls as we read about in Europe (the story of Don Juan).

A daughter must respect her parents and their wishes so as not to cause them sorrow. ${ }^{11}$

The rights of adat (local custom) were proffered here against the foolishness of Western custom. In Minangkabau novels at the time, this battle of Western-educated children against parental and adat claims dominated many plots, which often centered on choice of marriage partner..$^{12}$

The same year (1914) saw the publication of the volume (IXb3) dealing with women from the report of the Committee investigating declining Native Welfare in Java and Madura (Mindere Welvaart Commissie). ${ }^{13}$ This lengthy inquiry involved questionnaires to local officials, and it elicited numerous submissions. Volume IXb3 contained submissions from nine Javanese women commenting on what would be required to raise the status of women. Seven of these correspondents, ${ }^{14}$ including the well-known educator Dewi Sartica from Bandung, all mentioned the necessity of

8 Soenting Melajoe 3, 5 (January 20, 1914).

${ }^{9}$ See Taufik Abdullah, Schools and Politics: The Kaum Muda Movement in West Sumatra (1927-1933), (Ithaca: Cornell Modern Indonesia Project, 1971).

${ }^{10}$ Soenting Melajoe 3, 23 (June 5, 1914).

11 Soenting Melajoe 3, 25 (June 19, 1914).

${ }^{12}$ See Cora Vreede de Stuers, The Indonesian Woman (The Hague: Mouton, 1960), ch. 4, and Els PostelCoster, Het Omheinde Kweekbed: Machtsverhoudingen in de Minangkabause Familieroman (Delft: Eburon, 1985).

13 Onderzoek naar de Mindere Welvaart der Inlandsche Bevolking op Java en Madoera. IXb3: Verheffing van de Inlandsche Vrouw (hereafter referred to as Mindere Welvaart Report) (Batavia: Drukkerij Papyrus, 1914).

14 Raden Adjeng Karlina and Oemi Kalsoem from Yogyakarta, Raden Ajoe Ario Soerio Soegianto from Solo, Siti Soendari from Brebes, Djarisah and Dewi Sartica from Bandung, and Raden Ajoe Sosro Hadikoesoemo (a sister of Kartini). 
112 Susan Blackburn and Sharon Bessell

abolishing child marriage, and more broadly the need for women to be consulted about marriage partners. Dewi Sartica labeled child marriage "truly a cancer in the Native society, which must be rooted out ..."15 All argued that sound marriages could only be contracted when the parties involved were adult and had fully consented to the union, not been coerced by parents. Otherwise, warned Dewi Sartica, their children would suffer in turn and women might even be driven into prostitution by the breakup of marriage. The answer, they all agreed, was education: people who had been educated did not submit to "barbaric" customs.

Indonesian women clearly saw girls as the main beneficiaries of reforms that transformed family life so as to allow daughters to enjoy a prolonged childhood free from adult responsibilities and with access to modern education. The abolition of child marriage, part of this broad reform plan, was expected to lead directly to freedom of choice of spouse, more stable and healthy marriages, and better quality maternal care.

\section{The views of Indonesian civil servants}

The 1914 volume of the Mindere Welvaart Report was also interesting for the first public official analysis of child marriage by Dutch and Indonesian civil servants. One member of the Committee undertaking the inquiry was Raden Achmed Djajadiningrat, then the Regent of Serang (Banten), an area subsequently shown to have a high incidence of child marriage. ${ }^{16}$ In Serang, he reported, child marriage of girls seven to ten years old used to occur according to the custom referred to as kawin gantung (suspended marriage), whereby children were formally betrothed but actual consummation of marriage was delayed for four to six years. According to Djajadiningrat, however, in villages in the north of the district, the tradition recommending postponement of consummation had lost influence over the years:

Girls of seven to ten years were just given over to their husbands. The invitation to marry was sent out by the parents of the woman. The main motive was to marry children as quickly as possible. Moderately well-off parents, like farmers and traders sought a physically strong son-in-law to help them with their work. ${ }^{17}$ Religious people preferred santris (religious scholars) for their daughters, who would show them the way to God as they said. There were also those who claimed that good morals and marriage virtues were promoted by early marriage. If one waited until passions ripened, there was danger that the girl would make a choice from the heart and not the head.

The people of Serang claimed it was very dangerous to have a mature maiden or a young widow in the house: they were possessed by devils. It was quite a different matter with girls of seven to ten years who had no feeling for love. Love for the chosen spouse was urged on her by parents and when she came to the time of life when natural feelings began to speak, she was already a careful housewife.

The notion that by marrying their girls young they were preserving them from "being spoiled" was commonly advanced against the ethical claims of the opponents of child

\footnotetext{
15 Mindere Welvaart Report, appendix p. 24.

16 Volkstelling 1930 Vol. 1: West Java, (Batavia: Landsdrukkerij, 1932), p. 44.

17 This statement, frequently reiterated in explanations of child marriage, appears to indicate that child marriages in Java were usually matrilocal, at least in their early years.
} 
marriage. The Regent of Wonosobo also stated that the age of marriage was declining in his district; at the time of the Report, girls were usually married off at age ten to fifteen and boys at age thirteen to fifteen. Some thirty years before, he claimed, the average age was about five years older.

The two Regents summed up the main reasons for early marriages in rural Java in similar terms:

Because children went to work early, they grew up quickly.

Parents wanted to increase the size of the family rapidly, because children were later expected to look after their parents and/or the help of a son-in-law was desired.

Parents were keen to receive the contributions which guests customarily made at a marriage feast.

People were ignorant of the disadvantages of early marriage both for the couple and for their offspring.

Parents were anxious to find a man to care for their daughter at an early age for fear she would later "go astray" and lessen her chances of marriage.

The Javanese were conservative. ${ }^{18}$

Many of these reasons were also advanced in later years. They are based on certain common motives and shared assumptions: parental desire for gain through marrying their daughters, a conviction that childhood was brief, and a fear of the sexuality of girls.

The rest of the Report's notes on child marriage summarized further evidence and commented on the phenomenon. As against the observations of the two Regents and reports of a rise in the incidence of child marriage in twenty-six districts, it was noted that in twenty-seven other districts "this abuse" was declining, either for economic reasons (e.g. coolies were easy to get, so the labor of a son-in-law was less necessary; or the cost of living had risen, meaning dowry or wedding feasts were less affordable) or because "the European example" was spreading. In general, concluded the Report, "marriage was more a matter for parents than for the children involved, especially among the more well-to-do." Although many child marriages were no more than betrothals, there was no doubt where the Report stood on the matter; those who compiled the report believed early marriage led to divorce, to polygamy, and to the early physical decline of the wife.

The Dutch were most scandalized by the prospect of the early consummation of under-age marriages - the sexual violation of childhood-for it was on this point alone that they took legislative action. Article 288 of the Criminal Law Code of 1915 specified that "A man who has sexual intercourse with a woman whom he knows or may well suspect is not yet of marriageable age, and inflicts physical injury on her as a result, incurs a jail sentence of at most four years," with heavier penalties in case of more serious injury. ${ }^{19}$ As was later admitted, the law was unenforceable and not policed.

The Mindere Welvaart Report set the scene for later statements by Dutch and Javanese officials on the question of child marriage, for instance in the Volksraad

\footnotetext{
18 Mindere Welvaart Report, p. 6.

19 Volksraad Handelingen, June 24, 1922, p. 402.
} 
114 Susan Blackburn and Sharon Bessell

(People's Council) in the 1920s. In this advisory representative assembly, the subject of child marriage was raised on a few occasions, in 1922, 1927, and 1938. It was usually European members of the assembly who voiced concerns over child marriage. In 1922, for instance, Bergmeijer referred to reports from missionaries in Sulawesi and Central Java of the sufferings of very young girls at the hands of husbands who abused and abandoned them. ${ }^{20}$ His observations echoed the concern expressed in an earlier report from a Volksraad committee, where an unnamed member was reported as urging the government to pass a law forbidding child marriage. ${ }^{21}$ In response to this pressure, two Indonesian official members of the Volksraad, the Regents Djajadiningrat and Ariodinoto, argued that although there was room for concern about child marriage, they were certain that the custom would gradually decline with education and social change. Neither showed any sense of urgency about it. According to Djajadiningrat, little had changed in villages since he testified to the Mindere Welvaart Commissie eight years before, although among priyayi families girls were being married older:

Marriage of girls who have not yet reached marriageable age occurs in social circles where the influence of the West or of Western-oriented education is more or less non-existent. Among officials, for example, girls are as a rule not married before age sixteen. In villages, however, child marriage is still common. There girls of seven to ten years enter marriage with men, really youths, of usually not more than fourteen years.

Djajadiningrat was aware that "voices have been raised for the government to take measures against child marriage," but he wished to show that the matter was not as simple as many thought. For one thing, he said, there was no real evidence that girls suffered from it. Many people practiced kawin gantung, whereby parents delayed handing over the bride until she "shows the first signs of being a woman," presumably a euphemism for menstruation. "Also on the side of the husband generally great calm and caution is taken, as required by adat," and also as supervised by the girl's guardian (wali-mujbir). "For these reasons," he concludes, "it is very rare that in such marriages a woman suffers physical damage."

In these remarks, Djajadiningrat revealed a felt need to respond to what he clearly perceived as frequent critiques of child marriage by offering general reassurances that little harm was inflicted on girls married young. As evidenced by the 1915 legislation, however, Dutch officials did not always find such reassurances so compelling. They were more impressed by the next set of cautionary comments Djajadiningrat included.

The right of a father to marry his daughter off, even against her will, stands according to Muslim law, as soon as his daughter is marriageable.

This is probably the reason why Muslim Javanese, who commonly wish to retain the choice of their son-in-law, will not willingly give up rules sanctified by religion and marry their daughters off as early as possible.

Therefore I do not think it necessary or desirable for the government to take special measures against such adat customs.

Just as among the higher ranks of Native society, so too in the village, adat concerning marriage will gradually of itself change for the better. The signs are

20 Ibid., June 24, 1922, p. 418.

${ }^{21}$ Volksraad Afdeelingsverslag Ond.1-Afd.II-Stuk 6. 
Marriageable Age 115

already present; thus in towns where the ordinary villager often comes into contact with the intellectual section of the population, child marriage has almost disappeared.

Moreover it seems to me no bad thing that in the village, where life itself is virtually the only school, people have a right to determine the future of their children, including in the area of marriage.22

In these views Djajadiningrat was backed by Ariodinoto. While admitting that child marriage had "harmful results," he agreed that it could not be overcome by force: "we can only override it by reason, by the use of education." 23 The Director of Justice, responding to the debate in the Volksraad, showed a similar unwillingness on the part of the government to take action on the matter. ${ }^{24}$

\section{Dutch colonial views, 1920 s}

Behind the scenes, however, Dutch officials were less confident in their approach. During the 1920s they debated among themselves whether there was any effective action they could or should take on child marriage. The debate began with concern expressed by the Resident of Lampung over a "social evil" in his district, the custom of wealthy Lampungers marrying young girls who were treated as slaves. In fact, the Resident saw the custom of secondary wives in Lampung as a direct continuation of the taking of house-slaves, a practice declared illegal in the previous century. The problem was compounded by the recent trend among Lampungers to bring in girls from the neighboring province of Banten, where poor fathers sold their daughters into what was virtual captivity, since the girls were then forced to labor for their husbands in remote and unfamiliar locations. The fact that divorce was very rare among the Lampungers meant a woman's chances of escape were slim. ${ }^{25}$ It is notable that Dutch officials were inclined to view the ease and frequency of divorce in Java as a factor mitigating the harm of child marriage, whereas others saw the strong association between early marriage and divorce as evidence of the evil effects of the custom. While it is true that divorce meant that unhappy child marriages could be dissolved (unlike, say, the situation among the Hindus of British India where divorce was unacceptable), it had also to be remembered that under Islamic law women could initiate divorce only with the greatest difficulty.

The government addressed the problem of Banten girls in Lampung by appointing a "protector of Bantenese" in Lampung and spreading information on the Lampung situation in Banten. ${ }^{26}$ Nevertheless, the discussion led immediately into a wider debate about child marriage. The Adviser for Native Affairs, Kern, explained the customs of

22 Volksraad Handelingen, June 20, 1922, p. 240.

23 Ibid., p. 241.

24 Ibid., June 24, 1922, p. 402.

25 Letter from Acting Adviser for Native Affairs, 9/8/1921, Afschrift behoorende bij den missive van de Wd. Adviseur voor Inlansche Zaken dd. 14 Juni 1923 No. E/172 Geheim, Mailrapport 789x/21, Rijksarchief, The Hague.

${ }^{26}$ Letter from Adviser for Native Affairs to Director of Justice, 14/6/1923, No. E/172 Geheim, Overgelegd bij Mailrapport No. 1114x/25, Rijksarchief, The Hague. 
116 Susan Blackburn and Sharon Bessell

marriage among Indonesian Muslims at some length to the Director of Civil Service. ${ }^{27}$ "As a rule," he began, "it can be said that the peoples of the Indonesian Archipelago marry as soon as they are adults." But parents who wished to control the choice of husband often married daughters off while they were still children:

. . . child marriage is very extensively found in the Archipelago and must be considered an Indonesian institution . . . It is a principle of Dutch colonial government policy to respect native institutions, and it is therefore appropriate that our laws do not make child marriage a punishable offense.

Moreover, he believed that most marriages arranged for young girls were not in fact consummated until adulthood (kawin gantung), arrangements to which there could be no objection. Freedom of choice for girls obviously did not figure as a high priority with Kern.

Kern then considered the feasibility of government intervention. Legislation was unworkable and undesirable.

If one limits oneself to surveillance, then one would have to cover all non-adult girls who are unmarried, to make a judgment about whether they are already fully grown before they marry, or whether they can have intercourse with their spouses, and ... also keep watch on whether the husband does not by oversight sleep with the girl.

We cannot forbid under-age marriages. Where parents are determined to go ahead with it, and the bridegroom himself wants it, and the young woman experiences no damaging results, the matter is not heard about and still less is it provable. If the fact in itself is considered punishable, the result would be that police would need to have the power to force their way into houses where there are not yet marriageable girls to establish the fact [that sexual intercourse was occurring]. Legislators must not allow such intrusion into the most intimate affairs of the Native population except in the most necessary cases.

Elsewhere, in explaining why adultery by Native men is not punishable, it is urged that one of the principles followed in government policy for years is to leave the Native population as a rule in the enjoyment of their own manners and customs. Only when it is necessary for reasons of maintenance of public order may we depart from this rule.

In Bandung, according to Kern, the regent took strong action to prevent child marriage, which he interpreted as marriage under the age of sixteen, by requiring local Javanese officials to prevent such marriages being contracted. Kern noted that this action "aroused discontent." "I honor his courage and high conviction, but I wonder whether he is not taking on a heavier burden than is advisable. It is going against Muslim marriage law." It was one thing for a devout Muslim regent to interfere in that way, but if it were done on the initiative of a "heathen government" it "would become an assault on religion." In Kern's view, the only answer was to rely on the social evolution already under way in the Indies.

${ }^{27}$ Letter from Adviser for Native Affairs to Director of Civil Service, 9/1/1922, Afschrift behoorende bij missive van de Wd. Adviseur voor Inl. Zaken dd. 14/6/1923 No.E/172 Geheim, Rijksarchief, The Hague. 
Increasingly world traffic has broken the isolation of the Muslim world, calling forth comparisons of the position of women in Christian and Muslim countries which are to the disadvantage of the latter. Thus we see attempts to make a rational explanation of religious law, and more and more women raise their voices and urge more just treatment ... This movement of leveling up with the world outside Islam leads one to expect that early marriage will decline. Government can speed that process by promoting development [ontwikkeling] in general and of woman in particular.

To go further seems to me decidedly inadvisable.

The Director of Justice felt rather more concerned. In 1923 he acknowledged that there was pressure from some Regents and Residents in Java to take action against child marriage, and that there was evidence that although "people try to give child marriage the appearance of only a betrothal (kawin gantung), nevertheless the bodily immature but already married girl is misused, i.e. that what is called consummation or rather violation is not infrequent in child marriage." Article 288 of the Penal Code against injuring an immature wife through sexual intercourse was a dead letter, since it had never been publicized and "it would be extremely difficult to produce evidence of the crime." 28

The question is: what can the legislator do about this? He can, through legislation, as so many times has happened, exercise moral influence; he can unambiguously let it be known that child marriage is an anti-social and thus objectionable deed; he can through legislation lend support to the Regents, Patihs [vice-regents] and sympathetic Penghulus [ village chiefs] to fight against the evil of child marriage.

This need not happen by threatening punishment, which would not work ...

But although punishment is not threatened, it can be made objectionable and impermissible.

The way has been shown by what the Regent of Rembang has been doing for years, i.e. by forbidding marriage officials to contract a marriage if they know or must suspect that the bride is not yet marriageable.

Kern responded by reiterating that it was undesirable and unfeasible to interfere in deeply rooted practices which were often defended by Indonesians as supremely ethical. "It is obvious that too early marriage is harmful. It is desirable it should disappear. But Islamic law, as here received, condones it and one cannot oppose it without coming into conflict with the syari'ah [Islamic law]." 29

It seems that Kern did not win this argument-at least not immediately. In 1925 the Government Secretary issued a circular about child marriage to governors. ${ }^{30}$ Although there could be little objection to kawin gantung, the mere betrothal of a young girl, it

28 Letter from Director of Justice to Adviser for Native Affairs, 31/5/1923, Overgelegd bij Mailrapport No. $789 x / 21$, Rijksarchief, The Hague.

${ }^{29}$ Letter from Adviser for Native Affairs to Director of Justice, 14/6/1923, No.E/172 geheim, overgelegd bij Mailrapport No.1114x/25, Rijksarchief, The Hague.

${ }^{30}$ Circular to Governor of West Java and other heads of regional government from the Government Secretary, Westerouen van Meeteren, 14/12/1925, No. 403x, overgelegd bij Mailrapport no. 1184x/25, Rijksarchief, The Hague. 
118 Susan Blackburn and Sharon Bessell

said, in many cases consummation was not postponed and physical harm was caused to the young woman: "combating such marriages is urgent and is the serious duty of our government." The government had decided that legislation on the matter was likely to be as ineffective as relying on "the evolution of ideas of Native society itself," but it did rely on the personal influence of Native officials. "Various Javanese Regents have already given a good example by telling marriage officials to oppose marriages with not yet marriageable women," although "much tact and care are needed so as not to give occasion for complaint." The Government would also publish information in local languages about the physical and moral damage wrought by child marriage. And finally, in order to monitor whether "the evil of child marriage" was declining as a result of factors that had nothing to do with legal prohibition, the Government required officials to provide twice yearly statistics about the number of child marriages contracted in their areas. The colonial authorities' response again emphasized the need to protect children from harm.

In any event, neither of the surveillance measures proved feasible. Two years later another circular called off attempts to bring prospective brides before officials to ascertain whether they were marriageable. For many years, it noted, this had been done, and if the bride was found to be too young, the parents were "seriously advised not to go through with the wedding"; indeed in some places marriage contractors were instructed not to authorize such weddings. However, it had been decided that such actions were problematic. It was not feasible to require parents to call off a wedding when all the preparations had been made, and "there are widespread, understandable objections to interrogating young brides, because the questions asked are offensive to her feelings and those of her family members, besides the fact that such inquiries are conducted by men unknown to her." As a result, the Governor-General now wished to advise against such action. ${ }^{31}$

\section{The debate peaks}

By this time the interest in and concern about child marriage had grown considerably. Evidence of the views of Dutch feminists was to be found in De Vrouw in Huis en Maatschappij: Propagandablad voor de Vrouwenbeweging in Indonesie (The Women in the Home and in Society: Propaganda Paper for the Women's Movement in Indonesia), an unusual paper edited in 1926 by a Dutch feminist, Mevr. Corporaal-van Achterburgh, and written in both Dutch and Malay by European and Indonesian women. It was clearly motivated by a desire to bring women of different races together, at a time when, with the decline of the Ethical Policy and rapid growth in the size of the European community, such efforts were largely doomed. A number of Dutch writers in this paper reflected on the problems of Indonesian married life. For instance, it was noted in 1926 that "child marriages still flourish."

And with festivities the martyrdom of a child's soul is celebrated, tearing her from her childish games, forced into a whirlpool of passion which she doesn't understand, the victim of a man often three or four times older than her, sometimes grey-haired. Thus one sees in the villages, children with children at the breast...

31 Circular on Child Marriages, 26/8/1927, No. 1753/A2, overgelegd bij Mailrapport No. 1954/27,

Rijksarchief, The Hague. 
An end should be made to this. ${ }^{32}$

Another article deplored many aspects of Indonesian family life, including child marriage, as bad for children and thus for the character of the people. ${ }^{33}$

The campaign against child marriage was also growing amongst Western-educated Indonesians, who had not only increased in numbers but had also become well organized. The year 1928 represented something of a peak in their public activity on this issue. In December that year Indonesian women's organizations held their first congress in Yogyakarta. Child marriage featured prominently on the agenda of concerns expressed. Moegaroemah made a speech specifically on that topic, and an indefatigable campaigner against the oppression of women in marriage, Siti Soendari, also discussed it in her public speech. The Congress made a resolution to check child marriage (mencegah perkawinan anak-anak); every member was requested to make propaganda about the evil (buruknya) of child marriage and to ask civil servants to assist by giving information to the people (rakyat) about it. ${ }^{34}$

As a result of this congress, an umbrella organization of women's groups was formed, called Perikatan Perkoempoelan Isteri Indonesia (PPII-Federation of Indonesian Women's Organizations). Despite the strong stand on child marriage at the 1928 congress, it is notable that the issue rarely featured in PPII conferences in subsequent years. ${ }^{35}$ Along with other issues associated with marriage, it obviously proved too controversial for the Islamic women's organizations, which had the most members of any women's groups. To keep them in the federation meant avoiding divisive topics. After all, the largest Islamic women's organization, 'Aisjijah, would have had difficulty taking a stand against child marriage when it was named after one of the Prophet's wives who had been married to him at the age of six. ${ }^{36}$

Outside the constraints of the PPII, however, women continued to campaign against child marriage. It was precisely the refusal of the PPII to deal with issues such as marriage laws that contributed to the formation in 1930 of the more radical women's organization Isteri Sedar (Aware Women), which remained outside the federation. In the pages of its journal, Sedar, practices of forced marriage (perkawinan paksaan) and child marriage (perkawinan anak-anak) were denounced, and change was called for, not just in people's behavior but also in Islamic marriage law, on the grounds that women must have the freedom to control their own lives and that child marriage was likely to damage the health of both the wife and her offspring. ${ }^{37}$

Nationalist parties were also active in campaigning against child marriage. In 1928, for instance, the radical secular nationalist party Partai Nasional Indonesia carried an

32 De Vrouw in Huis en Maatschappij 1, 5 (November 1926).

${ }^{33}$ I. "Grepen uit het Indonesische Gezinsleven," De Vrouw in Huis en Maatschappij 1, 8 (February 1927).

34 Congres Perempoean Indonesia jand Pertama, 23-25 December 1928 di Mataram (Djokjakarta: Isteri, n.d.).

${ }^{35}$ Issues of Isteri, the journal of the PPII, rarely broached the topic, and even when they did so it was with caution, never advocating government action.

36 Consultation of two Islamic women's organization journals from the colonial period, Isteri-Soesila Taman Moeslimah (Solo, 1924-1926) and Soeara 'Aisjijah (Yogyakarta 1932 and 1941-1942) revealed no articles on child marriage.

${ }^{37}$ See Isteri 1, pp. 9-10 and 11-12 and 2, pp. 5 and 8. 
120 Susan Blackburn and Sharon Bessell

article by Seti Rahajoe in its paper, Persatoean Indonesia [Unity of Indonesia], arguing that Indonesia needed freedom for women as much as national independence:

Are women free? Far from it! Just look at forced marriage (dwanghuwelijk) and child marriage; look at polygamy ... . How can our land be independent when women are still so restricted by all kinds of bonds? The future of our country is in the hands of women; they are the main educators of our children. ${ }^{38}$

Also in 1928 the secular nationalist Dr. Soetomo, leader of the Indonesische Studieclub in Surabaya, produced a book entitled Perkawinan dan Perkawinan AnakAnak (Marriage and Child Marriage), significantly published by the governmentowned Balai Pustaka, dedicated to issuing improving and informative works in Malay. ${ }^{39}$ As the only book published by an Indonesian on the subject of child marriage, it deserves close scrutiny here.

\section{Soetomo on child marriage}

His book puts Soetomo squarely in the league of nationalist social reformers. A medical doctor by profession, Soetomo announced in his Introduction that his intention was to write a book to be read by "civil servants, teachers, doctors and others who on account of their position and daily work have the opportunity to lead the People (Rakyat) from a dark world into the light" (6), a phrase that immediately evokes the title of the selection of Kartini's letters published by the Dutch Ethical Policy follower, J. H. Abendanon: Door Duisternis tot Licht (Through Darkness to Light). Soetomo forms a bridge from Ethical Policy attitudes to those of the nationalist movement, continuing thus: "There are many conditions and rules in our Indonesian society which need to be examined if we intend to gain a respected place amongst other nations, which is what we very much desire." (7)

One of those conditions in need of scrutiny was clearly marriage customs. Soetomo took great pains in this book to convince his Indonesian readers that the spirit of Islamic ideas on marriage was perfectly compatible with modern Western notions. The book was liberally sprinkled with quotations from the Koran and hadis side by side with J. S. Mill, Western sociologists, and the new guide to modern marriage, Dr. Th. van de Velde's Het Volkomen Huwelijk (Ideal Marriage), published in $1926 .{ }^{40}$ Soetomo started out confidently: "It is certain that a marriage which is intended to last forever, regardless of circumstances, must be based on a firm love, mutual respect, giving oneself to the other" (12), and cited van de Velde's four conditions of love and happiness: sound choice of spouse; health; agreement about children; and wellmatched sexual desire. (21) This approach would lead to healthy partners in marriage (the current concerns about disease, especially venereal disease, were prominent here) and marrying at a later age when an informed choice could be made by both parties. Fortunately, he claimed, such ideas were now being adopted in Indonesian society, particularly among educated people.

38 Cited in L. Kwantes, ed., De Ontwikkeling van de Nationalistische Beweging in Nederlandsch-Indie: Een Bronnenpublicatie, vol. 3 (Groningen: Wolters-Noordhoff, 1981), p. 81.

${ }^{39}$ R. Soetomo, Perkawinan dan Perkawinan Anak-Anak (Weltevreden: Balai Pustaka, 1928).

$40 \mathrm{Th}$. H. van de Velde, Het Volkomen Huwelijk. Een studie omtrent zijn physiologie en zijn techniek, voor den arts en den echtgenoote geschreven (Leiden: Ledische Utg-Mij, 1926). 
About half the text of the book and all its lengthy appendices (speeches and regulations) concerned child marriage. Soetomo observed that marriage customs differed around the archipelago and explored the reasons for early marriage. In his view, economic factors were prominent: the fact that life was not difficult for most people made early marriage possible, and for farmers the labor of a son-in-law was welcome. In addition, he accepted that parents "fear they may not be able to influence their daughter when she is mature"; she might play around and ruin her parents' reputation and her own. (30) In pursuit of a definition of "marriageability" for girls, he explored the age question, noting that "on average in Indonesia girls begin menstruating at age twelve to fourteen." Soetomo argued that men who marry young girls "certainly would avoid the use of force" against their wives. "So we never hear charges of physical damage in marriage" (35), a rather naive statement one would imagine, considering how loath women (especially very young ones) are to raise such matters publicly; where and how would they do so, and with what consequences? As a result, he would not wish to rest his argument against child marriage purely on medical grounds or on the notion that early marriage led to sickly children. The birth of sickly children, he considered, might equally be caused by environment ("Evidence shows that the bodies of rich people are stronger than those of slum dwellers").

Soetomo's greatest objection to child marriage was that it represented a form of forced marriage, burdening children with responsibilities which they could not fully understand. (37) Moreover, child marriage frequently led to divorce, which "hinders good family life and is also a bad influence on the upbringing of children." (40). It was up to Islamic marriage officials, he claimed, to help stamp out the evil (kejahatan) of child marriage. Religious organizations, both Islamic and Christian, were already making praiseworthy efforts in this respect. In fact, Soetomo went to considerable lengths to document numerous cases where Islamic organizations (Moehammadijah, Partai Sarekat Islam, and Nahdatul Oelama) in recent times had criticized child marriage. The reason for this tactic is obvious: Soetomo was a secular nationalist with a dubious reputation among Islamic organizations, so he was out to bolster the Islamic credibility of his cause.

Apart from what he identified as the necessary and growing support of Muslim organizations, Soetomo hailed the women's movement as an ally, and urged Muslim women's organizations to join with others in a united front. Women's equality, he argued, would not harm society, and he pointed to Scandinavian countries as examples of the way in which women's movement towards equality had led to increased protection of children. Women's efforts would be necessary to improve society "because many things are felt by women which cannot be felt by men" and because "it is not possible for a young girl to fulfill properly the responsibilities of mother and housewife." (46) He referred to the work of Kartini-"She convinced men of our nation about the oppression [kelaliman] of men towards women"-and to the female contributors to the Mindere Welvaart Commissie. (47)

In conclusion Soetomo called on every right-thinking Indonesian to make child marriage a national issue. The government could do much through schooling, teaching young people to postpone marriage and respect women, and civil servants and penghulus also had a role to play. Pointing to the success of the government's campaign 
122 Susan Blackburn and Sharon Bessell

against opium-smoking, he hoped that the same kind of attitude change could occur in relation to child marriage. (48-49).

Soetomo's book judiciously blended the arguments against child marriage which every interested party-Dutch, nationalist, Muslim, and feminist-would wish to see expressed. As far as action was concerned, he called not for government legislation but for the raising of awareness which would lead to the internalization of changed values. It is very much what one might expect of an Indonesian nationalist reformer who saw social problems first-hand thanks to his profession. One might not be going too far, either, to discern in his thinking on this issue the influence of his wife, a Dutch nurse whom he held in high regard. 41 This book was more outspokenly "pro-woman" than any of his other writings and distinguished him as possibly the sole male nationalist who took up what were usually regarded as "women's issues" as significant in themselves, rather than just trying to recruit women into the nationalist movement. The distinction here is, however, a fine one; for Soetomo, child marriage was a nationalist issue, because it affected the strength and reputation of the Indonesian nation.

\section{Colonial Government measures in the 1930 s}

Meanwhile, the Adviser for Native Affairs was saddled with the task of interpreting the semi-annual statistics on child marriage requested by the Government in 1925.42 For some years he wrestled with the motley collection of figures and comments provided to him by local officials (mostly local level Islamic marriage officials, with titles like naib, penghulu and lebe), becoming more and more frustrated in the process. The whole exercise faced insuperable problems.

First of all, there was no agreement among informants as to what constituted child marriage. In most cases, officials reported it to be either marriage of a girl below a certain age (anywhere from under nine to under sixteen years) or marriage before menstruation occurred, whichever came first. If the determination were based on the age criterion, there was no way of establishing exact age for most girls lacked proper birth registration, which did not exist in most villages. In many cases it was obvious that the 1927 circular that recommended against requiring girls to appear before officials to establish age was frequently being ignored. Witnesses were often called in to give evidence about age or an estimate was made by judging whether the outward appearance of the girl showed she had reached puberty ("form of bosom, hips and face"). If the determination of "marriageable age" were based on evidence of menstruation, no satisfactorily tactful and reliable way could be found to determine this, although in many cases again witnesses were questioned. Sometimes officials responsible for compiling the reports simply evaded the issue of definition, perhaps revealing how unfamiliar and incomprehensible the whole notion of child marriage was, or alternatively, revealing that they could not be bothered investigating it. In the

\footnotetext{
${ }^{41}$ See Soetomo's memoirs for his touching tribute to his wife: R. Soetomo, Kenang-Kengangan: Beberapa Poengoetan Kissah Penghidoepan Orang jang Bersangoetan dengan Penghidoepan Diri Saia (Surabaya: S. W., 1934), pp. 127-8.

42 These reports are to be found in the Rijksarchief: Letters from Adviser for Native Affairs (Gobee) to Governor-General, 30/8/1930 [No.1473/F-3] and 9/5/1932 [No. 698/F-3], overgelegd bij Mailrapport No. $1114 x / 25$.
} 
Western District of Borneo, for instance, child marriage was defined in circular terms as marriage where the girl was not yet marriageable, and in Benkulen and Aceh the bland statement was proffered that "Only marriages between marriageable persons are known."

The semi-annual reports contained a number of fascinating local variations in the monitoring of child marriage. In some districts (Krawang, Pamekasan and Temanggung) a girl was considered of marriageable age when she "has a dream of orgasm," presumably demonstrating that she was ready for sex. In Blitar, "to determine age, the circumference of the girl's head is measured with a thread, which is then laid on the girl's neck, and if the ends do not reach her nipples, the girl is marriageable." In many cases the girl had to run the gauntlet of so many interrogators that she (and her relatives) must have found it a humiliating (or farcical) experience, particularly considering that by this stage the wedding arrangements had mostly been completed.

Secondly, there was the vexing question of kawin gantung, a practice which existed under other names in many places. The report sheets required officials to specify whether the so-called child marriage was in fact a case of postponed consummation. Understandably, it was impossible to ascertain whether such postponement actually occurred. In some areas, officials insisted that only kawin gantung marriages were permitted for child brides, whereupon all early marriages were recorded as kawin gantung.

Finally, the statistics were often unbelievable. Even statistics provided for a single district, where presumably the criteria were constant, fluctuated in illogical ways, undermining their credibility and making it impossible to establish clear trends. Alternatively, credibility was weakened by the fact that lower officials would cease registering any cases of child marriage when they knew the local regent or resident was strongly against it, for fear of disapproval.

Despite the chaotic nature of the reports, the Adviser for Native Affairs found some value in them if only in the political sense that the requirement to collect them illustrated the government's concern about child marriage. This put pressure on local officials and fueled the efforts of non-government organizations, principally in the women's movement. Moreover, it was possible to draw a number of tentative conclusions from the collected data.

Firstly, it seemed to the Adviser that overall, the combined statistics and official comments which accompanied them showed that the incidence of child marriage was declining. The reasons advanced for this decline were many and varied, from the more predictable one-that people were becoming more educated and/or susceptible to pressure from their leaders, nationalists, and certain officials who opposed child marriage-to less obvious explanations. For example, in Grobongan regency it was reported that people had noted the bad consequences of child marriage, including the fact that "often there were love affairs here between the mother-in-law and the son-inlaw because the wife was still too young [for sexual intercourse], which resulted in violence" and because mishandling of young brides was also not uncommon. Similar observations came from Grissee, where according to the Regent, "fights often occur as a result of liaisons between mother-in-law and son-in-law," leading to parents-in-law 
124 Susan Blackburn and Sharon Bessell

"mostly trying to urge the son-in-law to resort to public women while he may not still sleep with his young bride."

Secondly, there was, of course, considerable regional variation in the apparent incidence of child marriage. In a few regions like West and Central Java and Solo, it appeared to be relatively high. In Serang Regency, for instance, in the period 1928-31 more than one thousand cases of child marriage were recorded every year. In the Outer Islands the only place registering significant numbers of child marriages was West Sumatra. As noted, however, reporting was dubious at best. At one point the Adviser had questioned the Aceh report that stated no child marriages had occurred in the region, calling the Governor's attention to Snouck Hurgronje's work, De Atjehers, which had documented cases of child marriage there. After that hint, the Governor obligingly came up with some figures registering child marriages, presumably gained by twisting the arms of the uleebelangs and other local heads who were responsible for providing them.

By about this time, the results of the 1930 census were becoming available. The census collectors reported the familiar problems of establishing age and incidence of child marriage. No exact ages were listed; instead, collectors were required to list every individual as belonging to one of three age groups. The first of these, infancy, was relatively easy since it covered infants who were not yet walking, but it proved extremely difficult to distinguish the boundary between the next two categories, nonadult and adult, especially since married girls were likely to be automatically classed as adult; as in the English language, it seemed virtually impossible to label a wife as a child rather than a woman, for marriage was regarded as a rite of passage. ${ }^{43}$ Assuming that the understatement of the level of child marriage was relatively uniform, however, one could still conclude from the census (see chart below) that the provinces with the highest rate were West and Central Java, followed by East Java, with some areas of Sumatra (Aceh, the north-east and the west) also showing relatively high incidence. In no district, however, was the percentage of girls listed as "non-adult" and "married" very high at all (rarely more than a few percent), leading the census compilers to conclude defensively that although there were undeniably "many married children," the problem in the Indies was less serious than in India; and in any case, they added, "such alliances are ... not always of long duration." 44

43 For discussion of age in the 1930 census, see Volkstelling 1930 (Batavia: Landsdrukkerij, 1936), especially vol. 1, p. 38, vol. 2 pp. 33-34, and vol. 8, p. 49.

44 Ibid., vol. 8, p. 51. In British India in 1929 research on age of marriage estimated that 42 percent of the female population were married before age fifteen (Forbes, "Women and Modernity," p. 413). It is unclear how reliable these figures were. 


\section{Married non-adult Indonesians according to the 1930 census (per 10,000 non-adults) ${ }^{45}$}

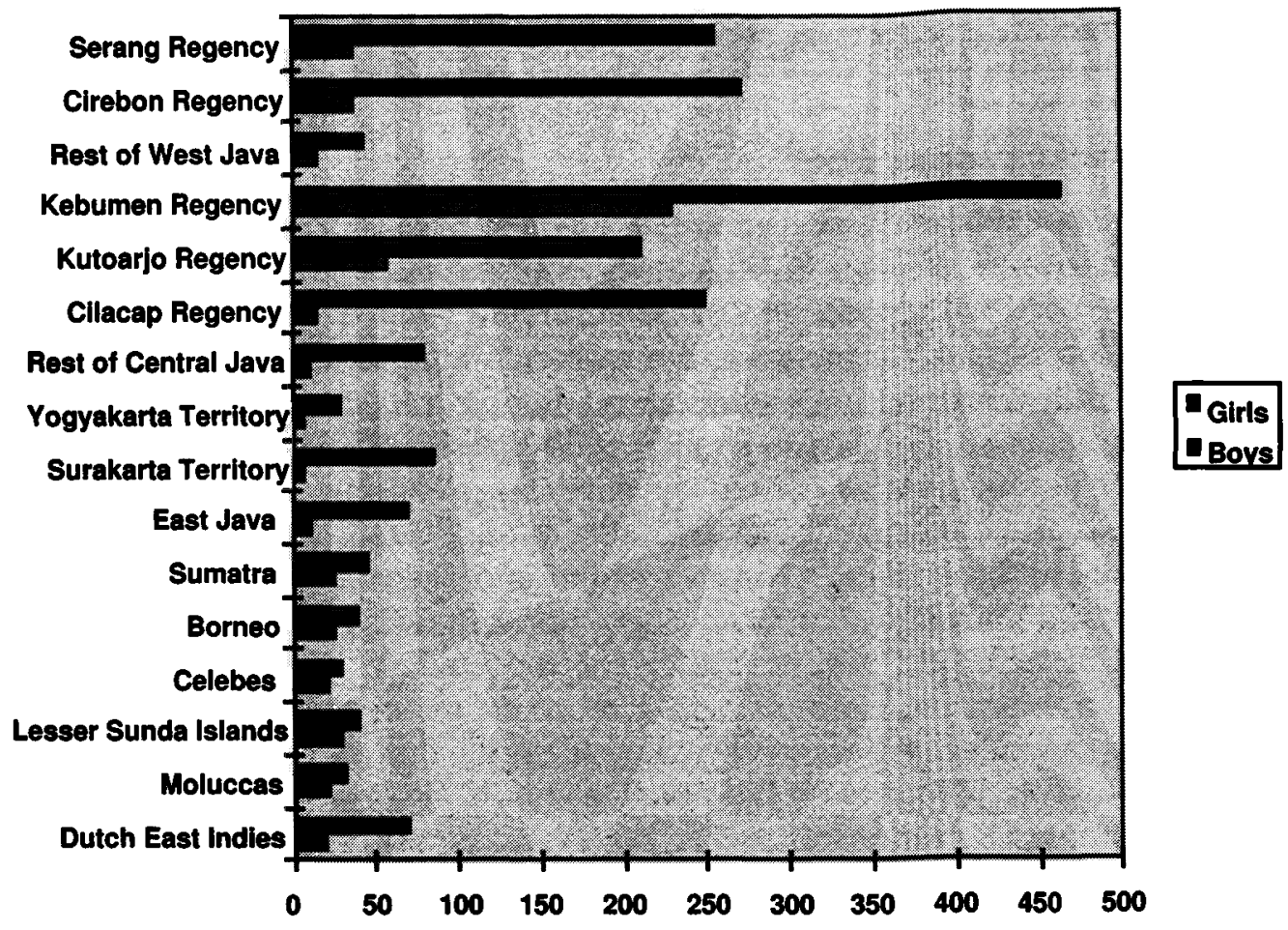

Even before the census results had been published, the government had decided that attempts to collect statistics specifically on child marriage no longer served a useful purpose. In June 1932 another circular was sent to officials requesting them to cease providing their semi-annual reports. The statistics had been unreliable, and in any case it seemed that as a result of "intensive combating" in many places, the incidence of child marriage was declining. Logically the latter conclusion must have depended more on impressionistic than statistical data.

Rejection of this practice can be left to public opinion. In the first place it rests with women's organizations to concern themselves with this matter; the GovernorGeneral thinks it desirable, although probably superfluous, to direct the executive of the PPII (the umbrella women's federation) to oppose child marriage. He urges you to cooperate with such organizations. ${ }^{46}$

The colonial government made one last and abortive bid to tackle the issue of child marriage head on. In 1937 it launched a draft of an ordinance for optional monogamous marriage for Muslims. Although the main thrust of the proposal was to offer Muslim couples the option of registering monogamous marriages, it also stipulated a minimum age for such marriages: eighteen for men and fifteen for

45 Volkstelling 1930, vol. 8, p. 25.

46 Circular on Combating Child Marriage, 1/6/1932, No.144/a, overgelegd bij Mailrapport No. 778/32, Rijksarchief, The Hague. 
126 Susan Blackburn and Sharon Bessell

women. ${ }^{47}$ Despite considerable support from some women's groups (notably Isteri Sedar), ultimately the ordinance proved unacceptable both to Muslim organizations and to nationalist parties which resented colonial efforts to interfere in personal affairs. The Government withdrew the proposal after only a few months' informal discussion. That was the end of its efforts at social reform in the area of Indonesian marriage practice.

Indonesian women's initiatives, 1930s

The Indonesian women's movement, however, pressed on with the campaign against child marriage. Women in Muslim organizations began to be more vocal on marriage issues, partly in response to the government's marriage ordinance project of 1937. At its 1938 congress, for instance, the women's wing of the Partai Sarekat Islam Indonesia (PI-PSII), which had never before made political statements, included some outspoken comments on the need to abolish child marriage. ${ }^{48} \mathrm{~S}$. Soemadhi denounced the marriage of young girls as caused by parental greed and likely to damage the health of mothers and offspring ${ }^{49}$. The executive of the PI-PSII had, she said, drawn up a plan to combat child marriage. ${ }^{50}$ Nyonya Abikoesno Tjokrosoejoso argued that those who practiced child marriage showed a lack of understanding of the spirit of Islam, as well as a lack of love and responsibility for the welfare of their daughters ${ }^{51}$. A statement by the executive claimed it had received many requests to consider the matter of child marriage. Although it acknowledged that according to Islam child marriage was lawful, nevertheless the practice should be opposed. Young girls were not capable of taking responsibility as housewives and mothers ${ }^{52}$. It is notable, however, that the organization still refused to set an appropriate chronological age for marriage, preferring the assessment to be left to individuals and, no doubt, wishing to avoid a confrontation with religious leaders on the matter. ${ }^{53}$

One woman who kept the issue in the forefront was Chairoel Sjamsoe Datoe Toemenggoeng, a Minang married to a colonial civil servant living in Batavia and active in the organization of the wives of Indonesian civil servants (Persatoean Isteri Pegawai Bestuur), for whom she edited the monthly journal Pedoman Isteri (Woman's Bulletin) in the 1930s. The pages of the journal occasionally carried articles opposing child marriage, principally arguing that the practice weakened the family. ${ }^{54}$ Nyonya Datoe Toemenggoeng also contributed a chapter entitled "Combating Child Marriage"

47 Ontwerp-regeling voor een monogaam huwelijk voor hen, wier huwelijksrecht niet bij algemeen verordening is vastgesteld, Mailrapport 309/20, Rijksarchief, The Hague. For discussion of the fate of the proposal, see Vreede de Stuers, The Indonesian Woman, pp. 108-110.

48 Boekoe Peringatan 'Pergerakan Isteri PSII' 1918-1940, n.pl., 1940.

49 Ibid., p. 45.

50 Ibid., p. 47.

51 Ibid., p. 58.

52 Ibid., pp. 69-72.

${ }^{53}$ A contemporary publication by 'Aisjijah, the modernist Islamic women's organization, makes no mention of child marriage. See Pemandangan terhadap pergerakan kaoem iboe oemoemnja dan 'Aisjijah choesoesnja, (Djokjakarta: Soeara 'Aisjijah, 1939).

54 e.g. Pedoman Isteri July-August 1935, May 1936 and July 1937. 
to the Indisch Vrouwen Jaarboek 1936 (Indies Women's Yearbook 1936), 55 a compilation of papers on women in the Indies by women of all races, directly descended from the paper De Vrouw in Huis en Maatschappij of the 1920s. After sketching the incidence and causes of child marriage along familiar lines, she condemned parents for "committing a crime against young children which can haunt them for their whole life". Better educated people, she claimed, were well aware of "the evil" and their efforts against it, combined with those of the Government and of civil servants, had led to a decline in the practice in recent years. How she could be so sure of this is unclear, since she admits to the many obstacles facing the campaign such as Muslim opposition based on the lack of a prohibition against child marriage in Islam, and the difficulty of ascertaining the age of girls. It is likely that the decline she observed was in urban society. Toemenggoeng acknowledged the value of Soetomo's book "in arousing concern in many circles" and praised women's organizations for doing likewise. As a result, she claimed, "people are slowly realizing that indeed child marriage is a cancer in our world which must be strongly opposed." In keeping with her constant assumption of the responsibilities of leadership, she concluded that "This task, i.e. of bringing this understanding to their uneducated [onontwikkelde] sisters, rests on the shoulders of those women who are called to it by their education and development." In short, Toemenggoeng's stance accords with that of Soetomo, crusading for a social reform by means of education. It should be noted that only 2.2 percent of Indonesian women were literate in 1930 , indicating that education still had a long way to go. ${ }^{56}$

In a similar vein, Nyonya A. Latip, another Sumatran resident in Batavia, also opened the pages of her women's magazine, Doenia Kita (Our World), published from 1937 to 1941, to expressions of opposition to child marriage and forced marriage. In 1938 an article by a Padang Panjang woman railed against the control of Minang girls' marriage by their mamak, ${ }^{57}$ a Palembang woman deplored marriages without love, determined by parental wishes, ${ }^{58}$ and another contributor regretted that there were still so many child marriages, particularly in the countryside, and urged the government and the women's movement to make people more aware of the issue..$^{59}$

Finally, at the end of the colonial period the women's movement began to take practical, if small-scale, action on marriage problems by setting up in 1939 the Consultatie Bureau Perkawinan (Marriage Consultation Bureau). By the time the women were married it was of course too late to prevent child marriage, but the Bureau began to document cases of abuse and abandonment which it judged to have resulted often from forced or child marriages. The aim of the bureau was to offer assistance and advice to women in such difficulties. Their evidence is particularly interesting in the light it sheds on cases of arranged marriage which never "took" because one partner refused to accept the other. Where this led to the wife being deserted without divorce, she was often in trouble, since under Islamic law it was very

\footnotetext{
55 M. A. E. van Lith van Schreven and J.H. Hooykaas-van Leeuwen Boomkamp (eds), Indisch Vrouwen Jaarboek 1936 (Jogjakarta: Kolff-Buning, 1936).

56 Volkstelling 1930 vol. 8, p. 29.

57 Rafi'ah Lathief, "Why is the divorce rate in Minangkabau so high?," Doenia Kita 1, 5 (March 1938).

58 Samina Said, "Musings of a Palembang girl: is it because of lack of education?," Doenia Kita, 1, 7 (May 1938).

${ }^{59} \mathrm{Rb} .$, "The direction that must be taken," Doenia Kita 1, 8 (June 1938).
} 
128 Susan Blackburn and Sharon Bessell

difficult for a wife to initiate divorce proceedings or to claim support. The Bureau helped some women work through these legal and financial tangles. 60

\section{Part II. "Early marriage" discourse since 1945}

After independence in 1945, Indonesian nationalists gained control of the state. For women's organizations, this event inspired the hope that governments would take stronger measures to improve the situation of women than had been prevalent during the colonial period. In 1946, shortly after the declaration of independence, the Ministry of Religion ${ }^{61}$ issued a law (Undang-undang No. 22 1946) concerning the registration of marriage, divorce and repudiation in Java and Madura, followed in 1947 by an instruction to marriage officials to discourage and avoid registering forced and child marriages. ${ }^{62}$ Maria Ulfah Soebadio, an active campaigner on women's issues and Minister for Social Welfare between 1945 and 1947, observed that in practice the instruction was not fully implemented, and suggested that this might be attributed to its relatively inferior status as an instruction. ${ }^{63}$ Certainly the instruction fell far short of answering the demands or allaying the concerns of women's organizations, which continued to lobby for more substantive reform, despite some internal disagreements about precisely what form any legislation should take.

During the 1945 to 1949 period, a number of women's organizations regrouped to form a successor to the pre-war PPII. They came together under the umbrella of Badan Kongres Wanita Indonesia (KOWANI), which was grounded in a common commitment to an independent and united Indonesia, within which the rights and status of women would be assured. In September 1949, the KOWANI Congress, held on the eve of the Round Table Talks, aimed to "impress on the leaders of those talks the absolute loyalty to and support of the undivided Republic by the women of Indonesia." The delegates also formulated a number of proposals aimed at elevating the position of women in the future Republic, including demands for legal and political equality between women and men and strategies to deal with illiteracy and make scholarships available for girls. ${ }^{64}$ Indeed, female education had long been a central concern for many women's organizations, and the typical cessation of a girl's education following marriage was one reason for opposition to early marriage. Conversely, education was considered to be an important instrument both in delaying marriage and raising the status of women.

Following the transfer of sovereignty in 1949, KOWANI was confronted by a difficult challenge: it now had to deal with the religious and political differences among various women's groups that had been largely subsumed in the common

\footnotetext{
${ }^{60}$ See Boekoe Peringatan Konferensi Badan Perlindoengan Perempoean Indonesia dalam Perkawinan (BBPIP) 2123 Juli 1939 di Mataram-Jogjakarta.

61 The Ministry of Religion was established by the new Cabinet of the Republic of Indonesia early in 1946 and was given responsibility for the registration of marriages, divorce, and repudiations.

62 See Nani Suwondo, Kedudukan Wanita Indonesia dalam Hukum dan Masyarakat (Jakarta: Ghalia Indonesia, 1981), p. 79, Maria Ulfah Soebadio, Perjuangan untuk mencapai Undang-undang Perkawinan (Suatu Pengalam) (Jakarta: Yayasan Idayu, 1981), p. 14-15, and Vreede-de Stuers, The Indonesian Woman, pp. 124-5.

63 Soebadio, Perjuangan, p. 15.

${ }^{64}$ Vreede-de Stuers, The Indonesian Woman, pp. 116-117.
} 
struggle for independence. ${ }^{65}$ There was, however, widespread consensus on the need for a national marriage law that would insure women's rights in marriage, with particular concern over polygamy, child marriage, and women's lack of rights within divorce. The 1950 Congress took up this issue, urging the Government to "issue new marriage laws which would protect women and to appoint as many women as men to the Committee of Investigation into marriage legislation that had already been established at the Ministry of Religious Affairs." "66 Throughout the ensuing two decades, the agendas of women's organizations were dominated by the issue of marriage law and efforts to have such legislation adopted.

In August 1950, in response to concerted lobbying by both women's organizations and female members of the Provisional Parliament, the government formed the Panitia Penyelidik Peraturan Hukum Perkawinan, Talak, dan Rujuk (Panitia NTR o $r$ Committee for Marriage, Divorce and Reconciliation) to examine the prospects for a new marriage law. In addition to investigating possible legislative approaches to marriage and divorce, the committee considered the question of whether Indonesia should have one law for all citizens, regardless of religion, or whether laws should be specific to particular religions. This issue continued to create division until the introduction of the 1974 marriage law.

\section{0s and 1960s: Issues, Debates and Draft Legislation}

In December 1952, Panitia NTR produced a draft law on marriage, presented to the Ministry of Religion in 1954, which advocated a minimum marriage age of fifteen for girls and eighteen for boys. ${ }^{67}$ This initiated an ongoing struggle between religious organizations and women's organizations, on the one hand, and between women's organizations and the parliament, on the other. ${ }^{68}$ For Muslim women's organizations the matter of child marriage, like the associated issues raised by the marriage law debates, was fraught with difficulties. Issues concerning the status and rights of women within marriage crossed religious as well as socio-economic lines, and for Muslim women the concerns were real and pressing. Because marriage legislation and reform had been defined as political actions that would help consolidate Islamic rights and integrity within the political realm, the public responses and positions open to women who organized under an Islamic banner or aligned themselves with particular Muslim organizations were limited. This was particularly true at flash points in the debate, such as during the Konstituante (Constituent Assembly) debates of the late 1950s, during the introduction of draft legislation in 1968, and in the period preceding the adoption of the 1974 legislation. Two legal commentators, Katz and Katz, have observed that the numerous proposals that were developed between 1945 and 1973 were all doomed to failure because "it was impossible to reconcile the interests of the

\footnotetext{
65 In 1950, at the 5th Congress, KOWANI was formally dissolved and replaced with Kongres Wanita Indonesia. This new organization performed a coordinating and administrative role and, unlike its predecessor, could not make decisions on behalf of its affiliates.

66 Ibid., p. 118.

67 Soebadio, Perjuangan, p. 15.

68 See ibid., Suwondo, Kedudukan Wanita; and Cora Vreede-de Stuers, "On the Subject of the 'RUU': The History of a Set of Matrimonial Laws," in Indonesian Women: Some Past and Current Perspectives, ed. Bob Hering (Bruxelles: Center d'Etude du Sud-est Asiatique et de l'Extreme Orient, 1976).
} 
130 Susan Blackburn and Sharon Bessell

conflicting groups," with Islamic groups favoring the status quo, Christian groups lobbying for initiatives that would reinforce their own marriage rules, and most women's organizations and some liberal Muslim groups advocating sweeping reforms. ${ }^{69}$

While the ensuing debates and the ongoing concerns of women's organizations regularly encompassed opposition to child marriage, the issues that dominated the discourse were polygamy and women's rights in divorce and inheritance, for legal discrimination against women as wives and inheritors was regarded as being most detrimental to their status. Moreover, these were the issues that posed the most direct threat to the interests of the women engaged in organizations and campaigns that favored protective legislation. Although early marriage remained an issue that occupied women's groups lobbying for reform, it was overshadowed by these other concerns. One explanation for this prioritization of grievances is the fact that marriage itself was defined as a rite of passage by which girls become women. ${ }^{70}$ In a society like Indonesia, where very few women remained single, those involved in organizations had already undergone that rite of passage, and while they remained concerned about the effect of early marriage on young girls, these women, having attained wifehood, were confronted by more immediate difficulties inherent in the institution of marriage. The rights of "adult" women elicited primary concern, and efforts were made at various junctures to emphasize the rights and needs of children, ${ }^{71}$ but child wives, often not in a position to speak on their own behalf, fell between these two categories. Moreover, the association of child marriage with life in rural areas tended to remove the issue to the periphery of the agendas of groups with a largely urban, and relatively educated, membership.

In the 1950s, however, girls continued to marry very young, with signs of a gradual change in the latter decade. According to the demographer Gavin Jones,

Age at marriage for girls was very low in Indonesia in the 1950s and 1960s. This represented the traditional situation with little evidence of change up to that time. The highest ages of marriage tended to be recorded in non-Muslim areas such as Bali, Maluku, East Nusa Tenggara, and the Minahasa area of North Sulawesi. Age at marriage began to increase during the 1960s. The conclusion from the 1973 Fertility-Mortality Survey was that in urban areas, the median age of marriage rose by 1 to 1.5 years over the decade of the 1960s, whereas in rural areas a slight increase in marriage age appeared to have started late in the $1960 \mathrm{~s}^{72}$

Opposition to child marriage was based on concerns about the implications for girls' health and education, and women's organizations spoke on behalf of those who

69 June S. Katz and Ronald S. Katz, "The New Indonesian Marriage Law: A Mirror of Indonesia's Political, Cultural, and Legal Systems," The American Journal of Comparative Law 23, 4 (1975), pp. 657-8.

70 That marriage is considered to be a rite of passage into adulthood is reflected in the 1979 law on Child Welfare, which defines a child as any person under the age of twenty-one unless already married.

71 The need to provide special protection to children was raised in the Konstituante. See Adnan Buyung Nasution, The Aspiration for Constitutional Government in Indonesia: A Socio-Legal Study of the Indonesian Konstituante 1956-59 (Jakarta: Sinar Harapan, 1992), pp. 223-224.

72 Gavin Jones, Marriage and Divorce in Islamic South-East Asia (Kuala Lumpur: Oxford University Press, 1994), p. 75. 
were married off, or likely to be married off, at an early age. As in the colonial period, child marriage was also often associated with forced marriage, where consent was absent and the girl might not have met her husband prior to the marriage, a state of affairs strongly opposed by a range of women's organizations and by (often female) representatives of political parties including Partai Komunis Indonesia (PKI-the Indonesian Communist Party) and Partai Nasional Indonesia (PNI-the Indonesian Nationalist Party). ${ }^{73}$

After 1965, the New Order government of President Suharto set new priorities for women. In particular, under this regime the state began to promote family planning in an attempt to reduce Indonesia's high growth rate. This policy influenced the state to support a rise in the age of marriage for girls, as part of an attempt to reduce the typical number of a woman's child-bearing years. In 1968, the government launched a national family planning program, and the issue was identified as a priority in the first two five-year development plans (1969-1979). In 1967 and 1968, two draft marriage bills were introduced into Parliament but were subsequently withdrawn by the government following fierce opposition from Muslim groups. ${ }^{74}$ In part, the need to slow population growth provided the impetus for these bills. In 1973, a report entitled The Status of Women and Family Planning in Indonesia was published, based on the work of a research team comprised of a number of individuals who had been active in the women's movement and in the campaigns to reform marriage laws. ${ }^{75}$ It concluded that although minimum age at marriage was rising, child marriages still occurred, particularly in the villages and especially in West Java. The report emphasized the need for comprehensive marriage legislation applicable to all Indonesia, arguing that: "[I]n connection with the age at marriage and matters concerning the improvement of the status of women in society, modern Indonesian women, as represented by the leaders of women's organizations, are of the opinion that of utmost importance today are education and matrimonial legislation." 76

In October 1970, Badan Nasional Koordinasi Kesejahteraan Keluarga dan Anak (the National Coordinating Body for Family and Child Welfare) conducted a workshop on Law Concerning Family and Children. ${ }^{77}$ One issue examined was minimum marriage age. The workshop rejected as too young both the existing minimum age for the Christian population and the age proposed in the 1967 draft Marriage Law for Indonesian adherents of Islam, each of which established a minimum marriage age of

73 This is reflected in the debates carried out during the time of the Konstituante which are summarized in Nasution, The Aspiration for Constitutional Government, pp. 220-223.

74 See M. Nasir Tamara, Indonesia in the Wake of Islam (Kuala Lumpur: Institute of Strategic and International Studies, 1986), pp. 16-17.

75 This team included Nani Suwondo who had been actively involved in Kongres Wanita Indonesia for many years and was vice president of that organization in the late 1950s. She was also editor of Karya (a weekly women's publication) and Suara Perwari (the magazine of the women's organization Perwari), and was the author of Kedudukan Wanita Indonesia dalam Hukum dan Masyarakat.

${ }^{76}$ T. O. Ihromi (project director), The Status of Women and Family Planning in Indonesia, A Study conducted by the Research Team on the Status of Women and Family Planning in Indonesia, Preliminary Report (Jakarta: 1973), p. 34.

77 In the late 1960s and early 1970s the BKNKKA, through a series of workshops, conferences and recommendations, sought to ensure that a range of problems facing children and youth were addressed through national policies and legislation. 
132 Susan Blackburn and Sharon Bessell

fifteen for girls and eighteen for boys. Instead, the workshop suggested a minimum age of eighteen for girls and twenty for boys, with the proviso that "if such [an agel is not yet possible, the minimum age should be sixteen for girls and eighteen for boys."78 Policy makers identified the establishment of a minimum marriage age as a primary instrument in efforts to reduce population growth.

The 1974 Marriage Law: controversies, compromises and impact

In 1973, a new marriage bill, applicable to all Indonesian citizens, was finally introduced by the Government. During 1973-74, the bill became a source of considerable tension between the various interest groups that had long debated the issue. In its final form, the legislation was a result of considerable compromise on a range of matters, ${ }^{79}$ and the minimum ages that were ultimately adopted were lower than those identified in the initial draft and advocated by a number of women's organizations and the official family planning policy. These compromises were concessions to Muslim lobby groups, both within and outside Parliament, who opposed the introduction of any legislation that they considered to be counter to the teachings of Islam. Although a vote within Parliament would have delivered a majority in favor of the bill from the Armed Forces Faction, the Government Party (Golkar), and the Indonesian Democratic Party, the extent and strength of pressure from sections of the Muslim community made compromise the only politically tenable course of action. ${ }^{80}$ The amended act was promulgated in 1974. Thus the New Order Government became the first in Indonesian history to succeed in passing national marriage legislation, but even such a strong and authoritarian regime was obliged to make concessions to Islamic opposition, notably in the area of minimum marriage age.

While the Panitia NTR had advocated a minimum age of fifteen years for girls and eighteen years for boys in 1952, by the late 1960s there was some support for legislation to adopt a later age. In February 1973, a consultation between members of Parliament (DPR) and members of KOWANI concluded that the appropriate minimum age for marriage was eighteen years for females and twenty-one years for males. ${ }^{81}$ In July of that year, draft marriage legislation was introduced to Parliament, advocating the ages suggested by the DPR-KOWANI negotiations. ${ }^{82}$ Ultimately, the 1974 legislation adopted minimum ages of sixteen and nineteen years for females and males respectively. The legislation further stated (article 6) that all persons under the age of twenty-one were obliged to obtain parental consent before marrying. Significantly, the legislation also stated that dispensation could be granted to allow the marriage of individuals who had not yet attained the minimum specified age. It did not, however, identify the circumstances that would justify underage marriage.

It is difficult to assess the impact of the 1974 Law on marriage age. The population censuses of 1971, 1980, and 1990 indicate an upward trend in marriage age in both

\footnotetext{
78 Ibid., p. 34.

${ }^{79}$ On the issue of polygamy, for example, the legislation, while promoting monogamy did allow for a man to take more than one wife under certain conditions. See Articles 3,4 and 5.

80 See Katz and Katz, "The New Indonesian Marriage Law," pp. 660-666.

81 See Soebadio, Perjuangan, p. 17.

82 Ibid.
} 
urban and rural areas and among both males and females. ${ }^{83}$ Census results also confirm earlier evidence that a far greater percentage of girls than boys marry before the age of twenty. For the youngest cohort included in the censuses, that is the ten to fourteen age bracket, the discrepancy between boys and girls is somewhat less than for the fifteen to nineteen years' age group, but the incidence of early marriage remains significantly higher among girls. There is variation between provinces, with some, such as West Java, continuing to show a higher incidence of early marriage. Trends towards later marriage are more pronounced in urban than in rural areas, and studies in Java have shown that the move to later marriage is strongest among the urban middle class. ${ }^{84}$ Nevertheless, in rural areas there is also an identifiable trend towards later marriage: between 1971 and 1980, the percentage of girls aged between ten and fourteen who were already married declined from 2.56 to slightly less than 1.0; for the fifteen to nineteen years' age group, the percentage of girls already married dropped from 41.11 to 34.63 . Thus, while child marriage (referring to marriage of girls under age fourteen) is, according to official figures, becoming relatively infrequent, marriage remains widespread among girls below the age of twenty, and the term "early marriage" usually relates to the fifteen to nineteen years' age group. ${ }^{85} \mathrm{It}$ is, however, impossible to ascertain from census figures the percentage of girls who marry under the legal age of sixteen, as the age cohorts used are organized by categories that measure the number of girls married under age fourteen and those married between and including the ages of fifteen to nineteen.

A central question is the extent to which the introduction of the 1974 Marriage Law has been responsible for the upward trend in marriage age. Writing in 1978 about the impact of the 1974 Marriage Law, Katz and Katz claimed that while it was relatively easy for "persistent couples to get around the new minimum age standards, the fact that the law states a minimum age seems to have had an influence on attitudes towards early marriage". ${ }^{86}$ Some more recent studies have also attributed the steady increase in female marriage age to the 1974 legislation. ${ }^{87}$ As indicated above, however, there were signs that the practice of marrying off very young girls, in many cases before puberty, was declining before the introduction of age restrictions. ${ }^{88}$ Jones has argued that the 1970 s witnessed a "revolution in marriage patterns after at least half a

83 It must be emphasized, however, that these figures should be used only as a guide and not regarded as providing a definitive picture of child and early marriage in Indonesia. While the majority of marriages are now registered, the difficulty in accurately establishing age at marriage casts some doubt over the accuracy of the figures.

84 Anju Taj, Gender, Intergenerational Relations and Marriage Patterns in Indonesia (Michigan: UMI Dissertation Services, 1990), p. 56.

85 Child marriage for these purposes refers to girls under the age of fourteen, while early marriage refers to the fifteen to nineteen age group.

86 Ibid., p. 314.

87 See Jutta Berninghausen and Birgit Kerstan, New Paths: Feminist Social Methodology and Rural Women in Java (London: Zed Books, 1992), p. 164, and Dianne Wolf, Factory Daughters: Gender, Household Dynamics, and Rural Industrialization in Java (Berkeley: University of California Press, 1992), pp. 61-2.

88 See Hildred Geertz, The Javanese Family: A Study of Kindship and Socialization (New York: Free Press of Glencoe, 1961), p. 56. Geertz noted that while most Javanese girls had been married, at least briefly, before the age of sixteen or seventeen, the age of marriage was gradually increasing and the marriage of prepubescent girls had become rare. These observations are supported by population censuses. 
134 Susan Blackburn and Sharon Bessell

century, and probably much longer, of near stability," whereby the marriage of girls under the age of sixteen became less frequent. ${ }^{89}$ The origins of this transition appear to predate the 1974 law. Indeed, the 1973 Indonesian Fertility-Mortality Survey concluded that the "new Indonesian marriage law may merely be following behind the social trend." $" 90$

However, research carried out in the Bangkalan regency of Madura in 1977 suggests that, at that time, the marriage of girls under the age of sixteen remained commonplace and was widely accepted within the community. The study found that, of the 130 village heads interviewed, only approximately one in four knew the legal minimum age for marriage. ${ }^{91}$ That few people in rural areas, including community leaders and local officials, were conversant with the new law indicates that both the debate about the appropriate regulation of marriage, including minimum age, and the impact of the law itself was, initially at least, were confined to a relatively small and elite group of political, religious, and social organizations. This is not unexpected; the Bangkalan study notes that the community was rather isolated, and thus slow to receive information. Moreover, because marriages below age sixteen are not permitted without special dispensation, it is likely that they are vastly understated in the statistics. Anecdotal evidence shows that some local officials collude with parents in disguising child marriage: false certificates of age are issued or age is incorrectly recorded at marriage. Corruption makes this possible, especially if a pregnant girl needs to be married off quickly, but cultural attitudes are also still important: particularly in strongly Islamic areas many people still consider it desirable that girls be married as early as possible. 92

Over time, legislation is likely to be one contributing factor to increasing marriage age, particularly in urban centers and in areas where the flow of information is effective and government campaigns have engendered a response. In rural and remote areas, the impact of the legislation is likely to have been limited, as indicated by Afdol's observations in Madura. Other factors, including increasing the participation of girls in primary school, have probably been significant. Changes in the nature of marriage, particularly greater spousal choice and a move towards the convergence of marriage ceremony, consummation, and cohabitation as opposed to kawin gantung, are also conducive to later marriage. ${ }^{93}$ Further, greater employment opportunities for girls in some areas, resulting from the expansion of the industrial sector from the mid-1980s and the feminization of the industrial labor force, have been identified as determinants

\footnotetext{
89 Jones, Marriage and Divorce in Islamic Southeast Asia, p. 76.

90 Indonesian Fertility-Mortality Survey 1973 (Jakarta: Universitas Indonesia, Fakultas Ekonomi Lembaga Demografi, 1974), p. 12.

91 Afdol, Effectiveness of the Minimum Marriage Age Law in Bangkalan (Singapore: Institute of Southeast Asian Studies, 1979), especially pp. 20-23 and 25.

92 For accounts of the continued practice of child marriage since 1974, see Siwidana, "Kasus Lumajang: Pemecehan atas Masalah Perkawinan Bawah Umur," Pelita 8, 2324 (22 December 1981) parts I and IV, and "Perkawinan dan Kehamilan Wanita Muda Usia Perlu Penanganan Serius," Suara Merdeka 33, 240 (October 16, 1982).

93 See Terence Hull and Valerie Hull, "Changing Marriage Behavior in Java: The Role of Timing and Consummation," Southeast Asian Journal of Social Science 15, 1, (1987), especially p. 107, and Taj, Gender, Intergeneraional Relations, p. 6 for a discussion of these changes.
} 
in increasing marriage age and spousal choice among teenage girls by giving them a somewhat greater degree of control over their lives. ${ }^{94}$

\section{The 1974 Marriage Law in policy context}

The 1974 Marriage Law and efforts to increase minimum age are best understood in the context of broader policy objectives of the New Order. Of particular significance are the prioritization of population control; an emphasis on universal basic education; and official formulations of appropriate roles for women, particularly within the domestic realm. Taken together, these policies have aimed to recast notions of marriage and family and reshape perceptions of both women and children within those institutions and within society more broadly. They have also been important in influencing the priorities and responses of various actors in relation to early marriage.

As discussed earlier, a primary motivating factor in official efforts to introduce a minimum age for marriage was the identification of such legislation as an instrument of family planning. This objective is clearly articulated in the legislation itself, with the clarification of the 1974 Marriage Law (paragraph d) identifying a close relationship between early marriage and rapid population growth, stating that a lower age limit for women equates to a higher birth rate. The primary objective in introducing a minimum age for marriage, then, is the attainment of the goals of family planning. According to Vreede-de Stuers, "after so many years of struggle and vain hopes the matrimonial legislation was only achieved thanks to the importance which the government attached to family planning."

In the late 1970 s and early 1980s, the government launched a campaign aimed at reinforcing the delay of first marriage for girls until the age of sixteen, that is the minimum age for marriage under the 1974 legislation. Further, the campaign encouraged women to wait until at least the age of twenty before having their first child. ${ }^{96}$ Adioetomo has explained this campaign as one aspect of official efforts to reduce the birth rate by maximizing the average age at which women marry and give birth to their first child. ${ }^{97}$ Since the mid-1980s, the government has encouraged a longer delay of marriage, with twenty identified as the preferred minimum age for females and twenty-five for males. ${ }^{98}$ In 1983, the Ministry of Home Affairs adopted a decree instructing local officials to encourage a minimum marriage age of nineteen for

\footnotetext{
94 See Wolf, Factory Daughters, especially pp. 214-216. Wolf notes a shift from earlier situations where economic autonomy women experienced in the past was not associated with control over the timing of marriage of the choice of spouse. By the 1980s, Wolf argues, "Factory workers' families received economic benefit from their working daughters and did not push them into early marriage as Javanese parents might have some years before," pp. 211; 214.

95 Vreede-de Stuers, “On the subject of the 'RUU,'” p. 88.

96 Sri Moertiningsih Adioetomo, Umur Perkawinan, Kelahiran dan Perencanaan Keluarga: Wanita di Jawa dan Bali (Jakarta: Fakultas Ekonomi Universitas Indonesia, 1983), p. 2.

97 Ibid., p. 2.

98 UNICEF, Situation Analysis on Children and Women in Indonesia (Jakarta: UNICEF, 1994), Draft, p. 76.
} 
136 Susan Blackburn and Sharon Bessell

females and twenty-one for males. ${ }^{99}$ Essentially, these official efforts to promote later marriage must be seen primarily in the context of family planning efforts. ${ }^{100}$

Official rhetoric, while emphasizing the family planning imperatives, has not overtly or directly focused on the health and educational implications of early marriage or on the rights of the girl-child. Indeed, policies dealing with children generally have emphasized areas of survival and development but have neglected areas of protection, including the protection of rights. ${ }^{101}$ Similarly, official responses to early marriage have not been characterized by any notion of a need to protect young girls from premature marriage. Nevertheless, the effort to extend basic education to both boys and girls, a cornerstone of New Order policy, has been an important factor in delaying marriage, at least into the early teen years. ${ }^{102}$ Early marriage, given its strong correlation with low levels of education, ${ }^{103}$ tends to work against the objective of universal education. ${ }^{104}$ The 1974 Marriage Law was introduced at a time when great emphasis was being placed on education, and the adoption of a minimum age for marriage, while not clearly identified as being central to education objectives, both complemented and reinforced those objectives. Efforts to keep children in the formal education system for a specified number of years have also contributed to a changing notion within society of appropriate activities and roles for children by promoting childhood as a prolonged phase that should be characterized by activities that are distinct from activities in the adult world. This notion is not easily reconciled with marriage or the role and image of $i b u$ (mother) or isteri (wife).

Child-focused organizations enter the scene

Since 1974, the issue of early marriage has not been featured on the agendas of women's organizations, although the marriage law itself has remained rather contentious. Rather, the domestication of women, state efforts to depoliticize the women's movement, and the exploitation of female labor have demanded a response from, and dominated the agendas of, many women's organizations. An examination of recent discourse on early marriage reveals that while the issue has slipped to become a topic of only marginal interest for women's groups who were previously the main advocates of later marriage, it has been taken up by other groups focusing on children's issues and rights.

99 Office of the Minister of State for the role of Women, Republic of Indonesia, The Changing Role of Women with Special Emphasis on their Economic Role (Jakarta: 1989), p. 48.

100 See Suwondo, Kedudukan Wanita, pp. 248-9.

101 Survival, development and protection make up the internationally recognised trilogy on which policies regarding children should be based. The lack of attention paid to issues of protection in Indonesia is reflected in rather weak policy formulations in the areas of child labor and juvenile justice.

102 Initially, all children were encouraged to complete six years of basic education, usually equating to an age of about twelve or thirteen years. In 1994, basic education was extended to nine years.

103 See Berninghausen and Kerstan, New Paths, p. 111.

104 Gender equity is a key principle of the policy of the Government's universal education policy.. While this objective has been reached in primary school enrolment, considerable discrepancies continue at junior secondary school and beyond. See Mayling Oey-Gardiner, "Gender Differences in Schooling in Indonesia," Bulletin of Indonesian Economic Studies 27,1, (April 1991): 57-91 for a discussion of gender inequality in the education system. 
The past decade has witnessed a proliferation of child-focused organizations guided by agendas that demand more than mere promotion of child welfare; such groups have adopted an empowerment- and rights-oriented approach to children's issues. In recent years, the issue of early marriage has been taken up, albeit in a somewhat peripheral way, by a small number of these groups advocating for children's rights, particularly the rights to education and to "childhood" as a time not only of learning but also of play and development. Early marriage is seen as contrary to the fulfillment of these rights. ${ }^{105}$ In 1992, one such organization, KOMPAK, published a comic book entitled Pengantin (The Bride) which illustrates the detrimental effect of early marriage on girls. It describes the marriage of a young girl, Riani, to a man almost twenty years her senior as follows:

All that remains is Riani with a broken heart, because of the loss of her childhood which should be a time of learning, laughter and play with other children her age. At the time she was not yet twelve years old. 106

The Bride describes the health risks associated with early marriage, discussing the plight of Riani's sister who, after being forced to marry at a young age, gave birth to a child who died and suffered severe health problems herself. While the physical risks of early marriage are identified as a prime reason for discouraging the practice, the notion of a child's right to childhood-"a time of learning, laughter and play"-also figures significantly in the didactic story. Here, KOMPAK draws a close connection between early marriage and premature entry to the workforce, noting that both are situations that rob children of their rights. KOMPAK works primarily with young girls who are employed in the industrial complexes on the periphery of Jakarta, but identifies a similar set of factors operating to push young girls into the workforce and marriage prematurely. These factors include poverty, the view that girls are and should be submissive and docile, and the neglect of children's rights. ${ }^{107}$

Another child-focused organization has raised concerns about the connection between early marriage and child prostitution. This NGO is currently in the process of initiating research into the extent and nature of child prostitution in Indonesian, which will include an examination of the marriage law, particularly minimum age regulations, and the consequences of early marriage. ${ }^{108}$ The high divorce rate among couples who marry when the girl is very young has, in some circles, been mooted as being one factor that may lead young divorced girls towards prostitution. ${ }^{109}$ Research carried out on prostitution by Jones, Sulistyaningsih, and Hull has also identified a link

105 According to the 1990 census, fewer than 1 percent of girls aged between ten and fourteen are married; 0.41 percent in rural areas and 0.16 percent in urban areas. For the fifteen to nineteen age cohort, however, the figure jumps to 18.19 percent for all females in Indonesia: 23.5 percent in rural areas and 9.06 percent in urban areas.

106 KOMPAK Indonesia, Pengantin (Jakarta, 1992), p. 18.

107 This position appears to be in contradiction to the findings of Dianne Wolf, mentioned earlier in this paper. It should be noted, however, that the girls that KOMPAK works with and on behalf of are, generally, aged between ten and sixteen, considerably younger than the women in Wolf's study.

108 Based on interviews conducted by Sharon Bessell in Indonesia in 1995 and personal correspondence. The organization concerned is SAMIN (Sekretariat Anak Merdeka Indonesia - Secretariat for Independent Indonesian Children).

109 Based on interviews conducted by Sharon Bessell in Indonesia in 1994 and 1995. 
138 Susan Blackburn and Sharon Bessell

between early marriage and prostitution. In the case of Indramayu, a province in West Java known to be a major source of prostitutes, early marriage together with low levels of education and high levels of divorce have been identified as reasons for the high number of sex workers. ${ }^{110}$ The connection between prostitution, particularly among underage girls, and early marriage has not been fully explored and any observations are, at best, tentative; they are also worthy of greater investigation.

That the issue of early marriage is receiving attention from some of these organizations is indicative of a greater recognition of childhood as an extended period during which rights as well as welfare should be acknowledged and advanced. The linkage of early marriage to notions of children's rights is, however, quite new and remains extremely tentative. Interestingly, the United Nations Convention on the Rights of the Child, the document from which many children's rights organizations draw their mandate, does not address the issue of early marriage. The Convention does, however, guarantee children's rights to participate in decisions concerning them (article 2) and to education (article 28). It also obliges States Parties to "take all effective and appropriate measures with a view to abolishing traditional practices prejudicial to the health of children." (article 24[3]) ${ }^{111}$

The international arena is, however, a source of pressure on the Indonesian government in relation to age of marriage. The United Nations body most concerned with children's affairs, UNICEF, has expressed concern at the continuing incidence of early marriage in Indonesia, and has periodically in annual publications noted the significant number of women who marry at or before sixteen years of age. For instance, its Situation Analysis of Women and Children in Indonesia in 1994 described the issue of early marriage as

complex because it is rooted in the beliefs and traditional social attitudes of people and is often exacerbated by poverty. Parents are often eager to marry off their daughters as soon as they reach puberty to avoid the stigma of remaining unmarried as well as being an economic liability in poorer households. ${ }^{112}$

Echoing the concerns of earlier proponents of later marriage, UNICEF draws links between early marriage and low levels of education on the one hand and high levels of maternal mortality on the other. The health risks associated with early marriage, and early childbirth, are underscored by statistics that indicate maternal mortality among women under the age of twenty is over 160 percent higher than that of women in the twenty to twenty-nine years' age bracket. ${ }^{113}$ Interestingly, these publications do not raise the possibility of physical harm due to premature sexual activity within this expression of concern about the health implications of early marriage. One reason may be that the issue as defined focuses largely on early marriage, that is marriage of girls between the ages of fifteen and nineteen years old, rather than on the child marriage of

\footnotetext{
110 See Gavin Jones, Endang Sulistyaningsih and Terence Hull, Prostitution in Indonesia (Canberra: ANU Working Papers in Demography No. 52, 1995), pp. 39-41.

111 For the purposes of the Convention, a child is a person under the age of eighteen, unless majority is attained earlier.

112 UNICEF-Government of Indonesia, Situation Analysis, p. 95. Also see UNICEF-Government of Indonesia, Situation Analysis on Children and Women in Indonesia (Jakarta: 1989), p. 85.

113 UNICEF-Government of Indonesia, Situation Analysis 1994, p. 95.
} 
pre-pubescent girls. It is significant to note that the Situation Analysis is a joint publication of UNICEF and the Government of Indonesia, indicating official recognition of the fact that early marriage continues despite a concerted effort by the government to encourage later marriage.

In 1991, UNICEF sponsored an information session and discussion on early marriage with a group of Muslim leaders (Ulama), which concluded that while Islam does not identify a minimum marriage age, later marriage is preferable to earlier marriage. ${ }^{114}$ UNICEF-Government of Indonesia Plan of Operations 1995-2000 for the first time explicitly includes an identification of, and strategies to respond to, vulnerable groups. This initiative, referred to as "project 11," includes persistent patterns of early marriage as one practice that has "serious consequences for the development of the girl child"115; it does not, however, identify a plan of action in regards to this matter.

\section{Conclusion}

In the course of the twentieth century the debate about marriageable age in Indonesia has waxed and waned in intensity, and the debaters and their arguments have shifted over time. Launched in the period of the Ethical Policy in the Dutch East Indies, a period where "social evils" in Indonesian society began to be identified and addressed, the debate reached a peak in the 1920s when women's organizations, secular nationalists, and the colonial state agreed on the need for social change. The possibility of government intervention was explored but largely rejected, both because of the practical difficulties involved and because the notion of minimum marriage age was too intimately interwoven with broader marriage law reform, a subject which proved to arouse too much opposition in strongly Islamic circles for any government to engage with it in a serious way until the New Order regime implemented the 1974 Marriage Law. In the meantime, as a result of other social and economic trends in Indonesian society, age of marriage began to rise of its own accord, reducing the urgency of the debate.

Those involved in the debate also entered and left the stage at different moments, following scripts that changed over time. Women's organizations were for many decades central players, speaking on behalf of the girls most directly affected by early marriage. From early in the century, young Indonesian women like Kartini deplored what they saw as the tragedy of girls forced into early marriages by their families, a tragedy that blighted both their childhood and adult lives by preventing them from gaining proper education and depriving them of control over their own futures. They argued, as well, that early child-bearing endangered women's lives, and they warned that such marriages might likely result in divorce and perhaps even prostitution among deserted young women forced to fend for themselves and their children. In the following years these concerns were taken up by women's organizations, both Dutch and Indonesian. After the 1930s, however, the salience of early marriage diminished in

\footnotetext{
114 Based on interviews with UNICEF representatives, conducted by Sharon Bessell, July 1995 . Also see Ajaran Islam dan Penanggulangan Perkawinan Usia Muda: Disusun atas Kerjasama Majelis Ulama Indonesia dan UNICEF (Jakarta, 1991).

115 Government of Indonesia-UNICEF Country Program Master Plan of Operations 1995-2000, unpublished document, p. 201.
} 
140 Susan Blackburn and Sharon Bessell

the agendas of women's organizations, in inverse proportion to the growing distance of their members from direct experience of the phenomenon. Statistics showed that child marriage became rare among urban and better educated women of the kind who joined women's organizations. Other aspects of marriage such as polygamy and divorce, which still affected middle-class urban women, completely overshadowed age of marriage in the platforms of these women's groups during the post-independence years. There was still, however, some awareness that other important "social evils" like prostitution and divorce were often connected to early marriage.

Where once the women's organizations had, in heartfelt tones, championed the cause of girls forced into marriage at an early age, in recent years it has been organizations acting on behalf of children who have taken up the matter, if only in fairly subdued ways. Such organizations may be international in origin, like UNICEF, or local, like Indonesian non-government groups. With the advent of these organizations, for the first time girls vulnerable to being pressured into early marriage have access to groups which claim to speak on behalf of children rather than adults, although the arguments used still echo the old ones, framed as they are in terms of increasing the life choices available to girls.

The colonial state approached the matter of child marriage with some trepidation. On the one hand, Dutch authorities felt some obligation to address the need for social reform and were particularly worried by the prospect of physical damage to prepubescent girls resulting from premature sexual intercourse. Yet they were only too aware of the practical problems associated with establishing a legal marriage age and the hostility likely to be aroused towards an alien government trying to intervene in matters of family and religious jurisdiction. After a few abortive forays into legislative and administrative intervention, colonial authorities seemed only too glad to hand the matter over to Indonesians themselves to deal with.

Indonesian civil servants trained in the Ethical Policy tradition of social reform were anxious to play their part in eliminating child marriage, but unwilling to see the colonial government embark on what they thought would be counter-productive legislation on the matter. They were confident that their own leadership by example and exhortation would produce change more effectively and certainly with less conflict. In the post-independence period few civil servants showed any interest in the matter, apparently feeling that the problem had all but disappeared.

During the colonial period, Indonesian nationalists like Dr. Soetomo crusaded against child marriage, identifying it as a slur on the nation and a debilitating force, likely to undermine efforts to build the foundation of a modern nation from a base of stable, prosperous, and educated families. In the era of independence such nationalists themselves held the reins of power, whereupon, like the colonial state, they too found it hard to disentangle marriage age from other intractable issues connected with marriage law reform. However, new reasons for championing the struggle against early marriage arose under the New Order regime after 1965: the desire to reduce family size strengthened the resolve of the state to push through legislation establishing a minimum age of marriage as part of its 1974 Marriage Law. Indonesia's vigorous family planning campaign has included pressure to raise marriage age as one way of helping to decrease population growth. 
In the long run, however, it is doubtful how important legislation or government efforts have been in raising the age of marriage, particularly since it seems many Indonesians are quite unaware of the legal minimum age. Change in attitudes has been the most important contributor to girls marrying later, and this is the result of many factors, including indirectly related social and economic changes (such as increased literacy and new employment opportunities for women) and also, more directly, the efforts of organizations and leaders of the kind referred to in this article.

Resistance to change has consistently been demonstrated by those who felt most threatened by change: families (particularly parents) who felt they were acting in the best interests of the group and the individual in marrying off young daughters, and devoutly Islamic groups who felt that an attack on early marriage was indirectly an attack on Islamic law, which had no concept of minimum age and permitted girls to be married off without being consulted. Over time it seems that both these sources of resistance have come to accept the desirability of later marriage for girls, in the belief that in a "modern" society longer schooling is required for girls and that adults make better mothers and wives. 
